\title{
Breeding population increase and range expansion of the Great Crested Grebe Podiceps cristatus in southeastern Norway
}

\author{
Svein Dale
}

Faculty of Environmental Sciences and Natural Resource Management, Norwegian University of Life Sciences, P.O.Box 5003, NO-1432 Ås, Norway. Correspondence; e-mail: svein.dale@nmbu.no

\begin{abstract}
The Great Crested Grebe Podiceps cristatus is listed as near-threatened on the Norwegian red list due to small population size, estimated in 2015 at 220-380 pairs. Population size is considered to be stable. Approximately one quarter of the population (50-100 pairs) is thought to occur in Oslo and Akershus, but this estimate is not based on detailed data, and the only previous systematic estimate was 90-100 pairs in 13 sites in 1982. In 2018, I conducted a comprehensive survey of all known and potential breeding sites to assess current population size in Oslo and Akershus. I recorded 233 pairs in 34 sites, suggesting a large increase in population size. To analyse the population increase in more detail, I collected all known records of Great Crested Grebes during the breeding season for the period 1995-2018. Analyses confirmed that there has been a strong increase, at a yearly rate of $4.2 \%$. The increase was both due to increases in already established populations (69\% of total increase), and establishment of new sites (31\%). New sites were colonised in particular the last 10-15 years, and new sites were located gradually further away from the sites that were already used in 1982, indicating continuous range expansion. New sites were also located in smaller, less nutrient-rich lakes at higher elevations, perhaps indicating occupation of lower quality sites that could limit further population increase. Similar population increases have also occurred in other parts of the distribution range of Great Crested Grebes in Norway, and I present a new population size estimate for Norway at 531-634 pairs. Hence, the species no longer qualifies for red listing, and one may consider to downlist the species to least concern.
\end{abstract}

Keywords: Great Crested Grebe, habitat quality, population increase, population size, red listing

\section{INTRODUCTION}

The Great Crested Grebe Podiceps cristatus is listed as near-threatened (NT) on the Norwegian red list (Kålås et al. 2015) due to a small population size $(<$ 1,000 reproducing individuals). The population size in Norway has been estimated at 220-380 pairs and is considered stable (Shimmings \& Øien 2015). A population of this size should normally be listed as vulnerable (VU), but the Great Crested Grebe was downlisted due to large populations in neighbouring countries (Sweden and Finland).

Oslo and Akershus counties in southeastern Norway have important breeding sites for the Great Crested Grebe (Dale et al. 2001). Approximately one quarter of the Norwegian population has been estimated to occur in these two counties (50-100 pairs; Shimmings \& Øien 2015). However, this population estimate was to a large degree based on reports submitted to the Norwegian Biodiversity Information Centre (www. artsobservasjoner.no) only during 2008-2014, which may not give a complete picture of distribution and population size. For Oslo and Akershus, there has only been one previous comprehensive assessment of population size, based on data from around 1980, which indicated 90-100 pairs (Olsen 1982).

To provide a reliable estimate of current population size, I surveyed all known and potential breeding sites for Great Crested Grebes in Oslo and Akershus during 2018. I compared counts from 2018 with previous estimates to assess population changes. I also collected all records of the species during the breeding season for the period 1995-2018 to quantify yearly changes. Historical records of Great Crested Grebes also provided data to analyse patterns of changes in distribution. In addition, I summarized current knowledge of total Norwegian population size based on up-to-date information from experts in each county. Overall, these data were used to evaluate whether the current red list status is justified.

The main finding of the study was that there has been a large population increase and expansion of the distribution range. To evaluate the potential for further population increase and range expansion, I analysed the spatial pattern of population change in Oslo and Akershus, and tested whether population increase was due to range expansion only, or a combination of range expansion and population increase in sites already occupied at the time of the study by Olsen (1982).

In addition, I tested whether recently colonised sites in Oslo and Akershus appeared to be of lower quality than those occupied earlier. If the oldest sites have become saturated with Great Crested Grebes, one would expect that surplus individuals produced at these sites would attempt to colonise new sites. However, over time all the best sites will be occupied and 
further expansion would have to be to sites of lower quality (Rodenhouse et al. 1997). Eventually, densitydependent reductions in breeding success at good sites, and low breeding success at low-quality sites would lead to a halt in population increase and thereafter stable population size (Rodenhouse et al. 1997). I tested these ideas by evaluating how three measures of habitat quality were related to patterns of range expansion.

As indicators of habitat quality I used lake size, nutrient level and elevation. Great Crested Grebes prefer large and nutrient-rich lakes (Haftorn 1971, Fjeldså 1994). Svensson et al. (1999) suggested that a population decline in Sweden starting in the 1980's was due to reduced input of nutrients into lakes. Svensson et al. (1999) also stated that lakes smaller than 10 ha were rarely used. Thus, smaller and less nutrient-rich lakes were assumed to be of lower quality. Furthermore, because Norwegian breeding sites are at the northern limit of the species' distribution range, higher elevation may limit reproduction due to e.g. later ice melt. Population expansion into smaller and less nutrient-rich lakes at higher elevation may therefore indicate that the population increase will slow down. In summary, the aims of the present study were to assess 1) current population size, 2) population changes, 3) red list status, 4) spatial patterns of population expansion, and 5) relationship between habitat quality and population changes.

\section{METHODS}

\section{Study area and field survey in 2018}

During 27 April-22 June 2018 I surveyed all potential sites in Oslo and Akershus counties for breeding Great Crested Grebes (Akershus was in 2020 included in the new Viken county together with former counties Østfold and Buskerud). These included all known breeding sites based on Olsen (1982), Dale et al. (2001), own observations thereafter, and reports submitted to the websites of the Norwegian Ornithological Society, Oslo and Akershus branch (www.nofoa.no) and the Norwegian Biodiversity Information Centre (www. artsobservasjoner.no). All known sites were in the lowlands ( $<220 \mathrm{~m}$ elevation). In addition, I surveyed all other lakes in the lowlands of Oslo and Akershus except a few small oligotrophic lakes situated within boreal forest that were unlikely to be suitable for Great Crested Grebes. In total, 260 sites were surveyed, and each site was surveyed once for approximately $15 \mathrm{~min}-1$ $\mathrm{h}$ depending on size, except Lake Hemnessjøen which took one day. Surveys were done using binoculars, but for larger lakes telescope $(25 \mathrm{x}-50 \mathrm{x})$ was also used.

Potential sites for Great Crested Grebes were considered to be limited to the lowlands of Oslo and Akershus because nutrient-rich lakes only occur below
$220 \mathrm{~m}$ elevation. This is due to nutrient-rich glacial clay sediments that were deposited in marine environments at the end of the last glaciation when sea level was 220 $\mathrm{m}$ higher than at present in the study area (www.ngu. no/nyheter/nytt-datasett-marin-grense). Above $220 \mathrm{~m}$ elevation there is mostly nutrient-poor moraine and lakes are generally oligotrophic (Økland \& Økland 1998). Most lakes above $220 \mathrm{~m}$ elevation have been visited regularly in recent decades so that the general absence of Great Crested Grebes from such sites has been confirmed by substantial field work. Also, this field work has documented one extraordinary case of Great Crested Grebes in one site above $220 \mathrm{~m}$ elevation (Stråtjern in Nannestad, 296 m elevation).

During surveys, I accessed viewpoints that together provided a complete or almost complete overview of each lake. I counted the number of adult Great Crested Grebes present. Generally, n observed individuals were considered to represent $\mathrm{n} / 2$ pairs (even numbers) or $\mathrm{n} / 2$ $+1 / 2$ pairs (odd numbers), following Woollhead (1987) and Keller and Korner-Nievergelt (2019). However, because nests may be concealed in vegetation, incubating individuals may be overlooked. Thus, I also evaluated the spatial distribution of individuals in each lake and in a few cases single individuals separated from others were considered to represent additional pairs (i.e. the estimated total number of pairs exceeded the formulas given above). Note, however, that I did not require direct evidence of actual breeding behaviour, so number of pairs could also include nonbreeding adults. According to Woollhead (1987), nonbreeders normally occur on larger lakes, and in Oslo and Akershus this may in particular be a possibility for Lake Hemnessjøen (a large lake with the largest number of individuals present during the breeding season). When analysing population trends, I therefore also evaluated results without including this lake.

\section{Historical data}

To assess changes in population size in detail, I collected historical records of Great Crested Grebes from the breeding season (May-July) in Oslo and Akershus. In addition to using own records, I searched the websites nofoa.no and artsobservasjoner.no, and published information (in particular in the journal Toppdykker'n published by the Norwegian Ornithological Society, Oslo and Akershus branch). For all sites holding Great Crested Grebes during the breeding season in at least one year, I also searched for visits during the breeding season with no Great Crested Grebes observed (negative records) to establish whether the species could reliably be recorded as absent in years when there were no positive records.

Negative records were based on reports that included records of at least some other wetland 


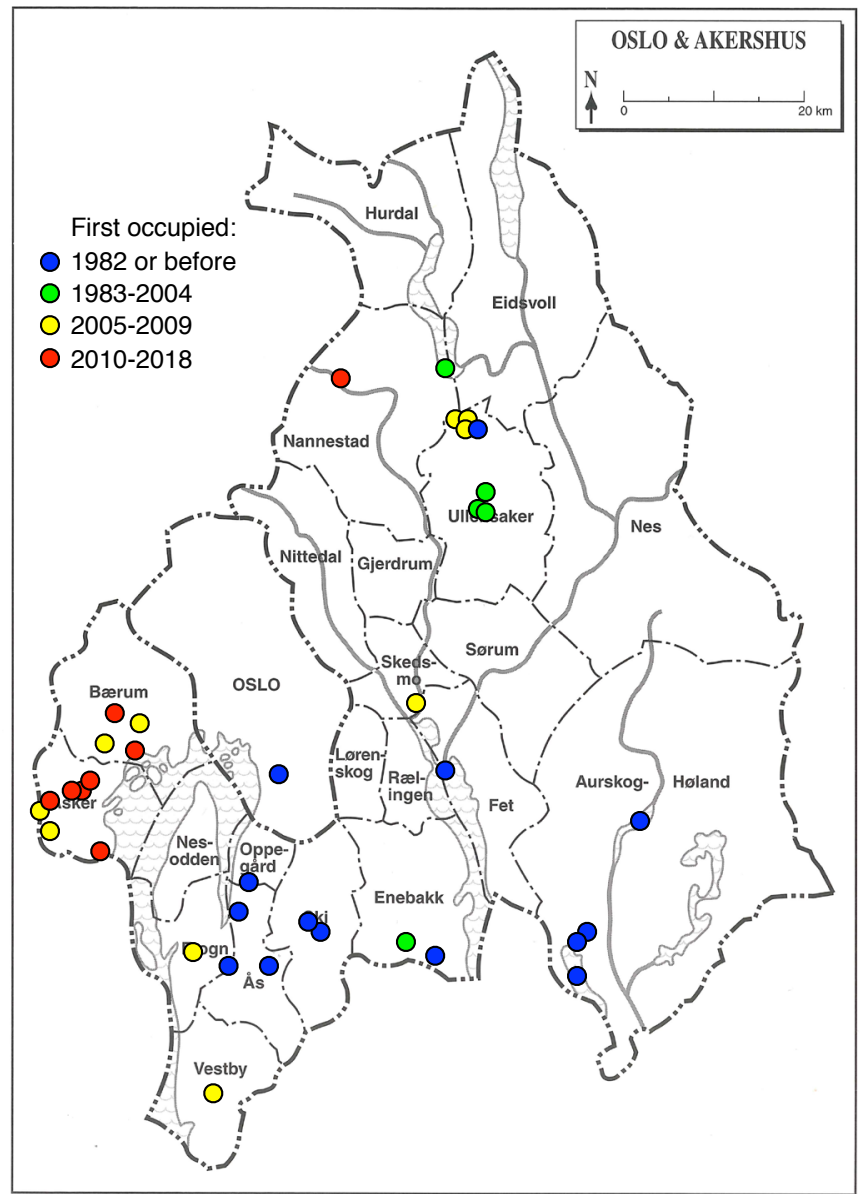

Figure 1. Distribution of breeding sites of Great Crested Grebes in Oslo and Akershus counties, southeastern Norway, occupied during 2010-2018. All except four sites were occupied in 2018. Colour of symbols indicates when sites were colonised.

bird species. Reports that mainly included rare or extraordinary species were considered likely to have omitted sightings of Great Crested Grebes, and they were not included as negative records. However, if the reports included common wetland species, I considered it likely that any sightings of Great Crested Grebe would also have been included. Thus, in such cases no record of Great Crested Grebe was interpreted as true absence, and included as a negative record.

Because most lakes were relatively small and fairly easy to survey, the number of individuals reported was regarded to represent an estimate of the total number of individuals. For some larger lakes, only limited portions are suitable for Great Crested Grebes, and reports from these specific parts of the lakes were regarded to represent estimates of the total number of individuals. One large lake with a large population size (Lake Hemnessjøen) represented a challenge, and only a few reports that were likely to represent complete surveys were included. For this and other reasons (see above; non-breeding individuals), I therefore also evaluated population trends without including this lake.

For sites already known by Olsen (1982), I assumed that any observations of adult individuals during the breeding season represented possible breeding pairs, and I calculated the number of pairs in the same way as described above for the field surveys in 2018. For sites colonised after 1982, only years in which pairs were observed during the breeding season were accepted as representing occupied sites until the first definitive breeding record (i.e. years with only records of single birds were excluded). After breeding was documented, I assumed that any observation of adult individuals, including single birds, during the breeding season represented possible breeding pairs. Sites with only a few observations of single individuals or pairs during the breeding season, but where breeding has not been recorded were excluded from analyses (see Appendix $1)$.

\section{Analyses of population change}

Population changes in Oslo and Akershus were analysed in two ways. First, I compared number of pairs recorded in 2018 with that reported by Olsen 
Table 1. Comparison of Great Crested Grebe population estimates for Oslo and Akershus counties, southeastern Norway, from 1982 (Olsen 1982) and survey results from 2018.

\begin{tabular}{lcc}
\hline Municipality & Pairs 1982 & Pairs 2018 \\
\hline Aurskog-Høland & $64-68$ & 89 \\
Enebakk & 5 & 23 \\
Ski & $4-6$ & 17 \\
Vestby & 0 & 1 \\
Ás + Frogn + Oppegård & $6-10$ & 43 \\
Oslo & $6-8$ & 16 \\
Asker & 0 & 11 \\
Bærum & 0 & 8 \\
Rælingen & $7^{1}$ & 1 \\
Skedsmo & 0 & 1 \\
Ullensaker & $1-2$ & 22 \\
Nannestad & 0 & 1 \\
\hline Total number of pairs & $90-100^{2}(100)^{1}$ & 233 \\
Number of sites & $13(14)^{1}$ & 34 \\
\hline
\end{tabular}

${ }^{1}$ Nordre Øyeren was not reported as breeding site by Olsen (1982), but 7 pairs bred in 1983 (Nordre Øyeren Fuglestasjon 1984). This site was included in analyses, giving a total population size in 1982(-1983) of 100 pairs.

${ }^{2}$ Olsen (1982) stated the total as $90-100$, but exact numbers were $86-99$.

(1982). However, Olsen (1982) did not include Lake Nordre Øyeren as a breeding site. According to Nordre Øyeren Bird Observatory (1984) the Great Crested Grebe was recorded breeding there in 1970 (one pair), and then again in 1983 (seven pairs). Thus, to avoid underestimating population size in 1982, I added the seven pairs to the total reported by Olsen (1982). Olsen (1982) reported a total of 90-100 pairs, although exact figures were 86-99. I therefore used 100 pairs as the total for 1982 .

Olsen (1982) included lake Hemnessjøen in the population estimate for Oslo and Akershus without stating any details. The lake is divided between the counties of Akershus (87\%) and Østfold (13\%). Thus, it is not clear whether Olsen (1982) excluded or included pairs breeding in the part of the lake that was within Østfold. However, most of the pairs in this lake breed within Akershus, in particular in the nature reserves Kragtorpvika and Kollerudvika. In 2018, only 7\% of the individuals were in the Østfold part of the lake. Thus, in the present study all pairs in Hemnessjøen were counted as belonging to Akershus, and it was assumed that Olsen (1982) also did so.

Second, I analysed yearly population changes based on the historical data. The amount of data was limited for the earliest period, as has been found in similar analyses for other species in Oslo and Akershus (Monthouel \& Dale 2019). From 1995, more data were available due to the initiation of a project of systematic surveys of the bird communities all over Oslo and Akershus (see Dale et al. 2001). Thus, I only included data for the period 1995-2018. Analyses were done with the package rtrim version 2.0.6 (Bogaart et al. 2018). This is a program for the analysis of time series of counts, using Poisson regression, and is particularly well suited for time series with missing observations for time points. Analyses were performed using model 2 , which assumes that populations vary across sites but show the same growth everywhere and that growth rates are constant during specified time intervals. Data used for analyses are shown in Appendix 2.

Analyses were done for the whole data set, and also separately for ,old' and ,new' sites (,old' sites were those already occupied in 1982, and ,new' sites those occupied after 1982) to test whether growth rates differed between these two groups of sites. Furthermore, analyses were also done excluding the site Hemnessjøen because this site had limited data and might also have non-breeders present. Finally, analyses were also done without data from 2018 because survey effort was larger in 2018 than in previous years.

I also summarized current population size in all counties with breeding populations of Great Crested Grebes in Norway by contacting local experts in each county. They provided updated population estimates for each county based on own field surveys and reports submitted to artsobservasjoner.no. Although eutrophic lakes are often visited by birdwatchers and numerous reports from such sites have been submitted to artsobservasjoner.no, it is possible that some potential breeding sites for Great Crested Grebes have not been checked. Thus, I consider that the population estimates presented here represent minimum numbers, and more thorough surveys may reveal additional breeding sites, although most likely only a few. Current estimates were compared to county-wise estimates reported by Shimmings and Øien (2015).

\section{Site variables and analyses}

Analyses of the influence of ecological factors on range expansion were done on data from Oslo and Akershus. For all sites holding breeding Great Crested Grebes in at least one year, I measured lake size and elevation using www.norgeskart.no. Data on nutrient level (phosphorus level measured as $\mu \mathrm{g} \mathrm{P} / \mathrm{l}$ ) were taken from the water environment website of the Norwegian Environment Agency (www.vannmiljo.miljodirektoratet.no), and included 33 of the 38 sites. I retrieved 1365 individual phosphorus sample measurements from May-October during 1995-2018. Mean phosphorus levels of the 33 sites were estimated from a GLM with year and date of samples as covariates and site as a fixed factor (analysis done with JMP version 14). To test whether 

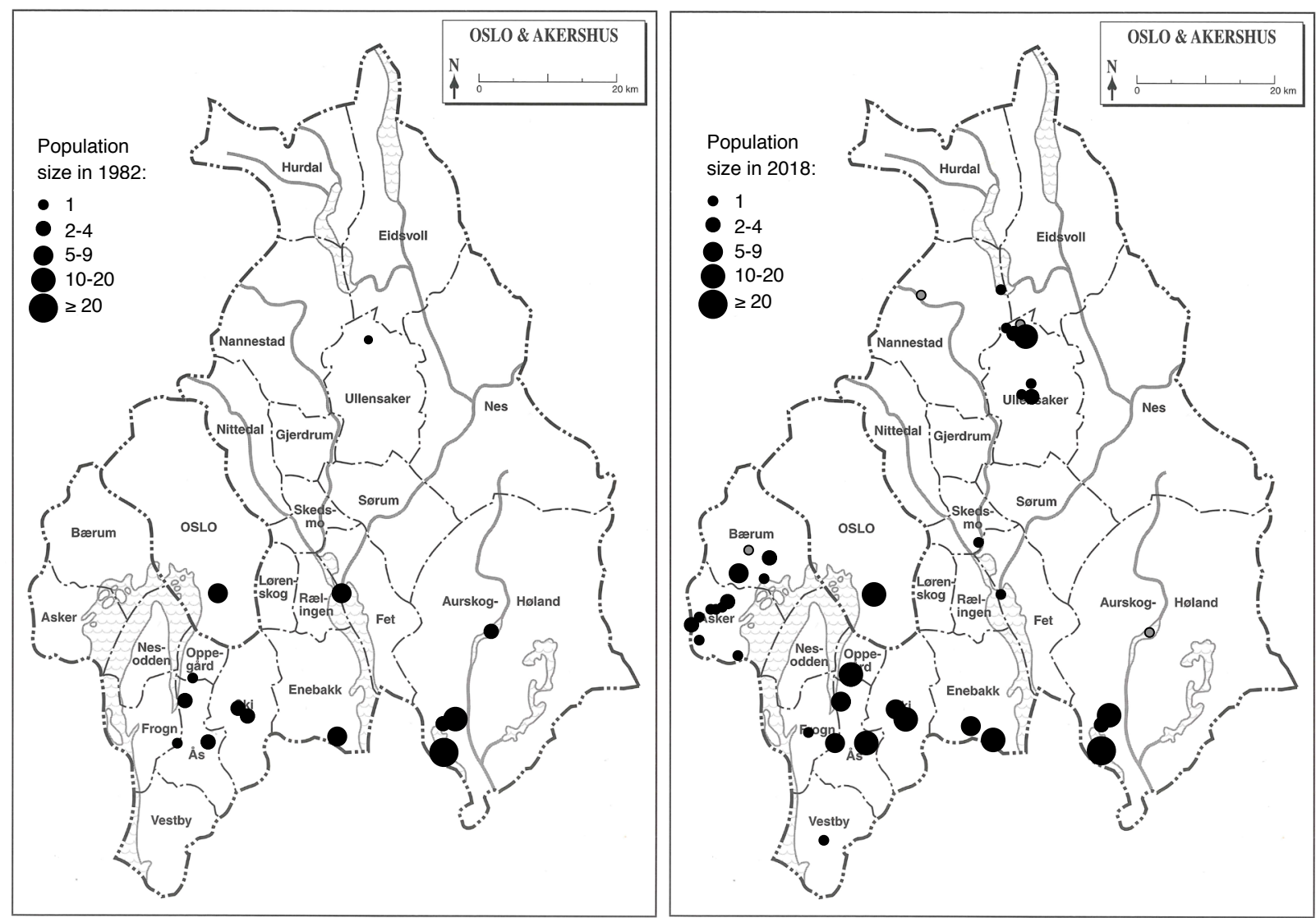

Figure 2. Population size of Great Crested Grebes in individual sites in Oslo and Akershus counties, southeastern Norway, in 1982 (left, based on Olsen 1982), and in 2018 (right). Grey dots for 2018 refer to four sites that were not occupied in 2018, but were occupied in at least one year after 2010.

newly colonised lakes were smaller, less nutrient-rich and at higher elevation than those initially occupied, I compared sites that were already occupied in 1982 and sites that were occupied after 1982 using MannWhitney U-tests due to non-normal distributions of variables (Siegel \& Castellan 1988). Note that although Nordre Øyeren was not reported as a breeding site in previous work (Olsen 1982), I included Nordre Øyeren as an ,old' site (see details in Appendix 2).

For the five lakes for which nutrient level measurements were missing, I evaluated nutrient level by considering the ecological environment of the lake (bedrock, soil, watershed conditions), using the nutrient level of neighbouring lakes with similar environments as references. To be conservative in relation to the hypothesis tested, values for old sites were in the lower range observed for similar sites, and values for new sites were in the higher range. Based on this I assigned the following values to these five sites; old site: Bråtevann $20 \mu \mathrm{g} P / 1$, new sites: Glittredammen $25 \mu \mathrm{g} \mathrm{P} / 1$, Oppegårdstjern $10 \mu \mathrm{g}$ P/l, Stråtjern $5 \mu \mathrm{g}$ P/l, and Risebrutjernet $30 \mu \mathrm{g} P / 1$.

For sites that were colonised after 1982, I recorded the first year a pair was present at a site, and the first year that breeding (including breeding attempts) had been documented based on the historical data collected. Within this sample of ,new' sites, I analysed whether lake size, nutrient-level, and elevation were related to the year of first use or first breeding. Furthermore, I also measured the distance between new sites and the closest old site, and analysed whether this distance was related to the year of first use or first breeding. This was done to test whether there has been a gradual expansion of the distribution range. All of these analyses were done with Spearman rank correlations due to nonnormal distributions of variables (Siegel \& Castellan 1988).

\section{RESULTS}

Population size in Oslo and Akershus in 2018 versus 1982

In 2018, 233 pairs of Great Crested Grebes were recorded in 34 sites in Oslo and Akershus (Table 1, Figures 1 and 2; sites are listed in Appendix 2). Compared to a population size of 100 pairs in 14 sites in 1982 (Table 1), this represented a $133 \%$ increase in number of pairs and a $143 \%$ increase in number of sites. 
Table 2. Comparison of Great Crested Grebe population estimates for Norway from 2008-14 (Shimmings \& Øien 2015) and 2016-19.

\begin{tabular}{lccl}
\hline County & Pairs 2008-14 & Pairs 2016-19' & Source 2016-192 $^{\mathbf{2}}$ \\
\hline Rogaland & $45-55$ & $90-100$ & Tor A. Olsen \\
Vest-Agder & $0-3$ & $7-9$ & Knut S. Olsen \\
Telemark & $0-1$ & 4 & Rune Solvang \\
Vestfold & $25-35$ & $45-55$ & Bjørnar Olsen \\
Buskerud & $10-15$ & $15-20$ & Steinar Stueflotten \\
Oppland & 15 & $60-70$ & Opheim (2017) \\
Hedmark & $1-2$ & $2-3$ & Jon Bekken \\
Oslo \& Akershus & $50-100$ & 233 & Present study \\
Østfold & $75-150$ & $75-150$ & Atle Haga \\
\hline Total & $221-377$ & $531-634$ & \\
\hline
\end{tabular}

${ }^{1}$ All data are from 2019, except Oppland (data from 2016) and Oslo and Akershus (data from 2018)

${ }^{2}$ Personal communications unless otherwise stated

The population increase was due to a combination of increase within sites already occupied in 1982, and the establishment of new breeding sites (Figure 2). On sites already in use in 1982, population size increased from 100 pairs in 1982 to 192 pairs in 2018 , i.e. accounting for $69 \%$ of the total increase. Sites colonised after 1982 had 41 pairs in 2018 , i.e. accounting for $31 \%$ of the total increase.

\section{Population changes in Oslo and Akershus during 1995 - 2018}

During 1995-2018, population size of Great Crested Grebes in Oslo and Akershus increased at a yearly rate of $4.2 \%(\mathrm{SE}=0.5, \mathrm{p}<0.01$; Figure 3$)$. The growth rate was similar when data from 2018 (my own field survey) were excluded $(4.2 \%, \mathrm{SE}=0.5, \mathrm{p}<0.01)$, or when data for lake Hemnessjøen were excluded (4.3\%,

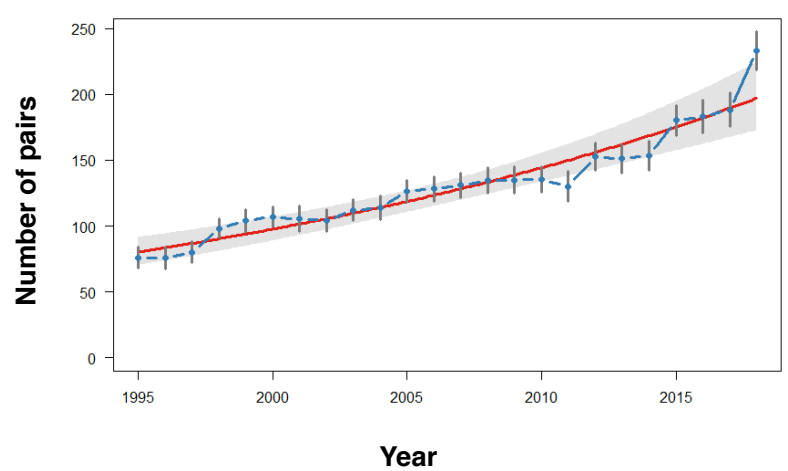

Figure 3. Estimated population size of Great Crested Grebes in Oslo and Akershus counties, southeastern Norway, during 1995-2018 (rtrim-analysis). Red line: overall population trend (shaded area shows $95 \%$ confidence interval). Blue line: estimated population size for each year (with SE error bars).
$\mathrm{SE}=0.5, \mathrm{p}<0.01)$. Note that estimated population size in 1995 (Figure 3) was below the estimate of 90-100 pairs by Olsen (1982). This suggests that there may have been a temporary population decline during 1982-1995. Population growth rate of sites that were already occupied by $1982(3.5 \%, \mathrm{SE}=0.6)$ was lower than that of sites occupied after $1982(8.9 \%, \mathrm{SE}=1.2$, $\mathrm{p}<0.01)$.

Increase in number of occupied sites in Oslo and Akershus

The cumulative number of sites occupied by Great Crested Grebes in Oslo and Akershus increased at a rate of less than one new site per year during 19952005 , but thereafter at a higher rate (Figure 4). The cumulative number of sites with confirmed breeding has in particular increased at a high rate during 201518. The recent expansion of the breeding distribution (Figure 1) has primarily been towards the west (Asker and Bærum municipalities) and within the northern part of the study area (Ullensaker and Nannestad municipalities).

In total, 38 sites have been occupied. All of these have been occupied after 2010 (Appendix 2). Only four of these sites were not occupied in 2018. However, one of these four sites was occupied both in 2017 and 2019 (Stråtjern, Nannestad). Risebrutjernet (Ullensaker) has only been occupied in 2009 and 2011, Glittredammen (Bærum) only in 2012 and 2013, whereas Bjørkelangen (Aurskog-Høland) has been occupied irregularly both before and after 1982 (Appendix 2). Overall, the majority of sites (27 out of $38,71 \%$ ) have been occupied in every year following first confirmed breeding (Appendix 2). 


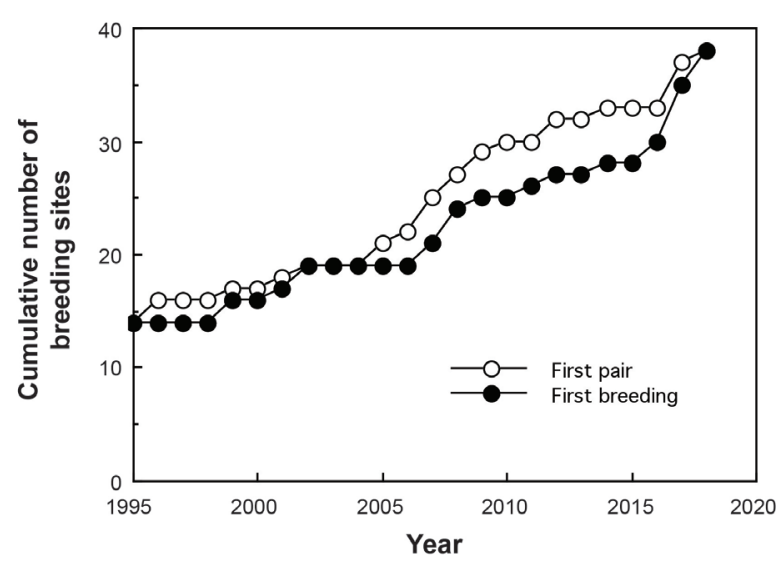

Figure 4. Cumulative number of breeding sites of Great Crested Grebes known in Oslo and Akershus counties, southeastern Norway, during 1995-2018. Breeding sites were defined as both the first year a pair was observed (open circles), and the first year breeding or breeding attempt was documented (filled circles).

\section{Spatial pattern of range expansion}

The distance between ,new' sites and the closest ,old' sites was positively and significantly related to both the first year a site was occupied $\left(r_{s}=0.55, n=24, p=0.009\right.$; Figure 5), and the year of first documented breeding $\left(\mathrm{r}_{\mathrm{s}}\right.$ $=0.47, \mathrm{n}=24, \mathrm{p}=0.025)$. Thus, sites further away from, old' sites took longer to be colonised (see also Figure 1).

\section{Lake size, nutrient level and elevation}

,Old' sites were larger (median $0.63 \mathrm{~km}^{2}$, range 0.28 $73.09, \mathrm{n}=14$ ) than ,new' sites (median $0.13 \mathrm{~km}^{2}$, range 0.01-33.21, $\mathrm{n}=24$; U-test: $\mathrm{U}=50, \mathrm{p}<0.001$; Figure 6a). However, among, new' sites there were no significant relationships between year of colonisation and lake size (year first pair recorded: $r_{s}=-0.26, n=24$, $\mathrm{p}=0.21$, Figure 6a; year first breeding: $\mathrm{r}_{\mathrm{s}}=-0.16, \mathrm{n}=$ $24, \mathrm{p}=0.43$ ).

,Old' sites had approximately twice as high nutrient levels (median 34.1 $\mu \mathrm{g} \mathrm{P} / 1$, range 9.5-159.2, $\mathrm{n}=13$ ) as ,new' sites (median $17.9 \mu \mathrm{g} \mathrm{P} / 1$, range $1.1-62.4, \mathrm{n}=20$; Figure $6 \mathrm{~b}$ ), although this difference was not statistically significant $(\mathrm{U}=91, \mathrm{p}=0.15)$. Analyses of nutrient levels that included estimated values for the five sites that lacked measurements (see Methods) indicated that ,old' sites tended to have higher nutrient levels (median $30.2 \mu \mathrm{g} \mathrm{P} / 1, \mathrm{n}=14$ ) than ,new' sites (median $17.9 \mu \mathrm{g} P / 1, \mathrm{n}=24 ; \mathrm{U}=94, \mathrm{p}=0.085$ ). Among ,new' sites there were no significant relationships between year of colonisation and nutrient level (year first pair recorded: $r_{s}=-0.24, n=20, p=0.30$, Figure $6 b$; year first breeding: $\left.r_{s}=-0.03, n=20, p=0.90\right)$.

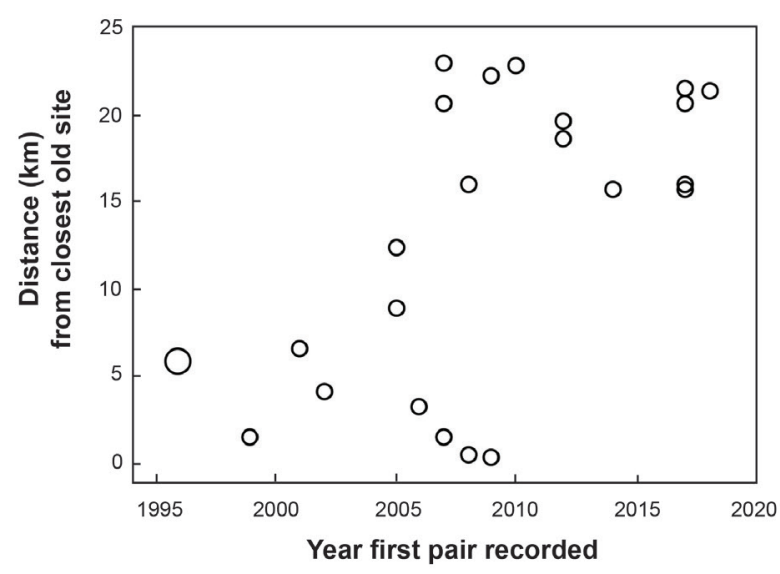

Figure 5. Range expansion of Great Crested Grebes in Oslo and Akershus counties, southeastern Norway: the distance between breeding lakes occupied after 1982 and the closest site that was occupied before 1982, in relation to when the lake was colonised. Larger symbols indicate overlapping data points.

,Old' sites were at lower elevation (median $126 \mathrm{~m}$ elevation, range $1-161, \mathrm{n}=14$ ) than ,new' sites (median $165 \mathrm{~m}$ elevation, range $0-296, \mathrm{n}=24 ; \mathrm{U}=97.5, \mathrm{p}=$ 0.024; Figure 6c). However, among ,new' sites there were no significant relationships between year of colonisation and elevation (year first pair recorded: $r_{s}=$ $-0.09, \mathrm{n}=24, \mathrm{p}=0.67$, Figure $6 \mathrm{c}$; year first breeding: $\mathrm{r}_{\mathrm{s}}$ $=-0.24, \mathrm{n}=24, \mathrm{p}=0.24)$.

\section{New national population estimate}

Total population size of Great Crested Grebes in Norway is now estimated at 531-634 pairs (Table 2), which is $67-141 \%$ above the previous estimate of 220 380 pairs (Shimmings \& Øien 2015). Population size has increased in nine out of ten counties compared to estimates given by Shimmings and Øien (2015) (Table 2).

\section{DISCUSSION}

Changes in population size and distribution in Oslo and Akershus

The present study indicates that the population size of Great Crested Grebes in Oslo and Akershus has more than doubled from 1982 to 2018. Olsen (1982) did not specify criteria for estimating number of pairs, whereas I used a liberal classification so that numbers may not be directly comparable. However, the large increase in population size was confirmed by rtrim-analyses which indicated a yearly rate of increase of $4.2 \%$ during the period 1995-2018. The increase estimated during the period 1995-2018 was based on data with similar 

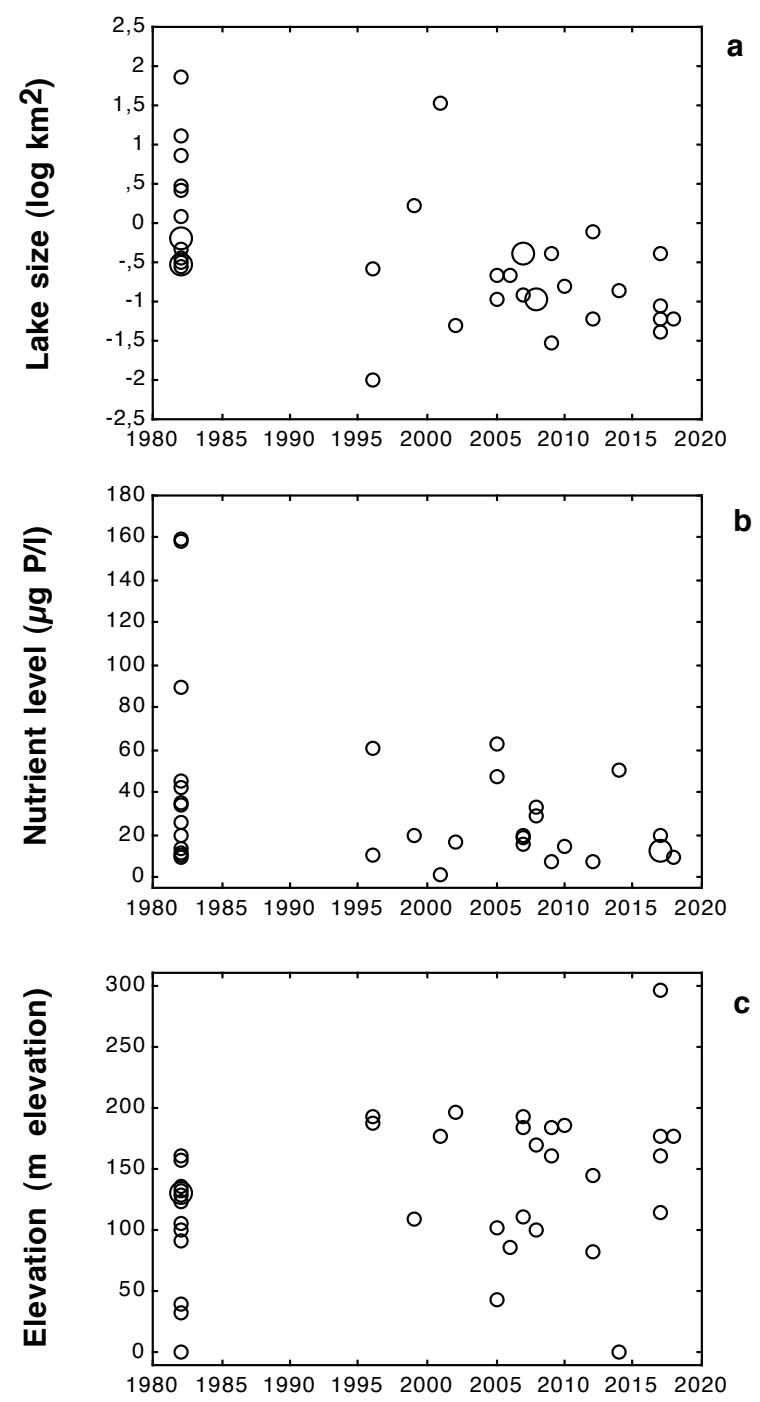

Year first pair recorded

Figure 6. Lake size (a), nutrient level (b) and elevation (c) of lakes occupied by Great Crested Grebes in Oslo and Akershus counties, southeastern Norway, in relation to when the lake was colonised. Sites already occupied in 1982 were all given the value 1982. Larger symbols indicate overlapping data points.

criteria, so for this period there should not be any methodological biases, and trends were similar when excluding data from 2018 and when excluding the most difficult site to survey (Hemnessjøen). Although the estimates may include some non-breeding individuals, this might also have been the case for the estimate by Olsen (1982). Based on own field observations, all sites are thought to contain mostly breeding individuals, although lake Hemnessjøen could have a proportion of non-breeders.

The present study also found that the number of breeding sites had more than doubled compared to what Olsen (1982) found. It is possible that some breeding sites were not checked by Olsen (1982) or others at that time. However, the recent expansion of the distribution range in particular into Asker and
Bærum municipalities is likely to be well documented because many lakes in this area have been visited regularly for a long time (Christiansen \& Kristiansen 1975, Bøhler 2010). In general, many of the other sites colonised after 1982 were also known by birdwatchers before 1982, in particular sites that now have several pairs of Great Crested Grebes. The sites that have been little visited by birdwatchers and may not have been surveyed by Olsen (1982) are some sites that still only have a single pair. Thus, it seems likely that only a very small proportion of the estimated population increase could be due to a lack of field surveys in the years up to 1982 .

I found that $69 \%$ of the population increase occurred at sites that were already occupied in 1982, whereas $31 \%$ of the increase was due to colonisation of new sites after 1982. However, the new sites had a higher population growth rate than old sites. It is difficult to evaluate the potential for further increase within established breeding sites, but breeding density is now 7.1 pairs $/ \mathrm{km}^{2}$ lake surface at the sites that were already in use in 1982 (excluding the two largest lakes that had only a few pairs). Population density in sites colonised after 1982 is now 6.7 pairs $/ \mathrm{km}^{2}$ (excluding the largest lake that had only a few pairs). However, there are few previous density estimates to compare with.

\section{Expansion into lower quality sites}

Sites in Oslo and Akershus that were occupied already in 1982 were larger than sites colonised after 1982. Svensson et al. (1999) stated that lakes smaller than 10 ha are rarely used by Great Crested Grebes. Among the 14 sites already occupied in 1982, all were larger than 28 ha. However, among sites occupied after 1982, $33 \%$ ( 8 out of 24 ) were smaller than 10 ha, and the smallest was 1 ha. These findings suggest that the range expansion has been into lower quality sites.

A similar pattern was found regarding nutrient level. Although not statistically significant (tests had p-values of 0.15 and 0.085 ), old sites had a nutrient-level that was approximately twice as high as sites colonised after 1982. Furthermore, among the sites already occupied in 1982, 62\% (8 out of 13) were still eutrophic (i.e. $\geq 20 \mu \mathrm{g}$ P/1) during 1995-2018. However, among sites occupied after 1982, only $30 \%$ (6 out of 20 ) were eutrophic, and a few were even oligotrophic $(<5 \mu \mathrm{g}$ P/l; Hurdalssjøen, probably also Stråsjøen). These findings also suggest that the range expansion has been into lower quality sites.

In the lowlands in Oslo and Akershus, the Great Crested Grebe now breeds in most larger lakes ( $>20 \mathrm{ha}$ ). However, two notable exceptions due to large size and a rich birdlife (Dale et al. 2001) are Lake Bogstadvannet (Bærum/Oslo) and Lake Maridalsvannet (Oslo) (Appendix 1). Despite quite many observations of 
Great Crested Grebes here in early spring, no breeding attempts have been recorded. Both of these lakes are fairly nutrient-poor; Bogstadvannet typically has a phosphorus level of $10 \mu \mathrm{g}$ P/l whereas Maridalsvannet normally has $5 \mu \mathrm{g} \mathrm{P} / \mathrm{l}$. Maridalsvannet is the main drinking water source for Oslo, and input of nutrients from human sources has therefore been minimized.

Old sites were at lower elevation than sites colonised after 1982. Among the latter, Stråtjern was the first and only site situated above the upper elevational limit of post-glacial marine sediment deposits (i.e. upper limit of eutrophic lakes). This site was colonised recently with incubation recorded in 2017, although Great Crested Grebes were not recorded in 2018. However, in 2019 two pairs were nest building in the lake (S. Dale, pers. obs.).

Overall, I suggest that the pattern of range expansion into smaller and less nutrient rich lakes at higher elevation indicates that lower-quality sites have been occupied after 1982. However, there was little evidence that colonisation year within the period 1995-2018 was related to habitat quality. I expect that sites colonised after 1982 would have lower breeding success or breeding output due to their lower quality compared to sites already in use in 1982. Further range expansion may thus be slower in the years to come. This could be tested in future studies by comparing breeding success in old and new sites.

\section{Management recommendations}

In Oslo and Akershus, the Great Crested Grebe has increased strongly in recent decades. About $40 \%$ of the population is currently breeding within nature reserves or other protected areas. Thus, the species does not currently need strong management actions. However, breeding pairs may locally be subject to disturbance from recreational fishing. One prime example is Stovivannet (Bærum municipality) where anglers walk through reedbeds to access open water, and thereby also disturb at potential breeding locations. Great Crested Grebes may not be able to cope with this kind of prolonged disturbance although they have some ability to adapt to human activities (Keller 1989).

\section{Red listing}

Population increases of the Great Crested Grebe have occurred in other parts of Norway as well, and total population size in Norway is now estimated at 531-634 pairs. This estimate is much higher than the previous estimate of 220-380 pairs given by Shimmings and Øien (2015). However, if the rate of population increase estimated for Oslo and Akershus is representative for the whole of Norway, then Shimmings and Øien (2015) have underestimated population size. This is clearly the case for Oslo and Akershus (cf. Figure 3), and perhaps for some other counties too.

The total number of mature individuals in Norway (estimate 1,062-1,268) has now already passed $>1,000$ individuals, and may increase further given recent and ongoing increases in many counties. If so, the ,Small population criterion' (criterion D1) should imply listing as near-threatened (NT; < 2000 mature individuals). Because populations in Sweden and Finland are still large and stable or increasing [Sweden: 22,000 pairs (Ottosson et al. 2012), 3.8\% yearly increase the last 20 years (Green et al. 2019); Finland: 25,000-35,000 pairs and stable (Väisänen et al. 2011)], downlisting to least concern (LC) should be considered.

However, data on habitat quality of new sites in Oslo and Akershus suggest that population increase may slow down in the future when all suitable sites have been colonised. Current carrying capacity for Great Crested Grebes in Norway is not known, and one could argue that for precautionary reasons a change in red list status should wait until total population size has been clearly above the 1,000 individuals limit for several years. On the other hand, the current estimate is already 6-27\% above the 1,000 individuals limit, and there is potential for further increases at least in some regions and for some years to come. Also, there are no current major threats to the population, and continuing climate change is likely to benefit the species in Norway (see e.g. Huntley et al. 2008).

Acknowledgements. I thank the Environmental Authorities of Oslo and Akershus County for financial support, local experts (see Table 2) for providing recent population estimates for other counties than Oslo and Akershus, and Geir A. Sonerud and two anonymous reviewers for comments on the manuscript.

\section{REFERENCES}

Bogaart, P., van der Loo, M. \& Pannekoek, J. 2018. rtrim: Trends and Indices for Monitoring Data. R package version 2.0.6.

Bøhler, T. 2010. Fuglelivet i Asker og Bærum 2010. Norsk Ornitologisk Forening, Asker og Bærum lokallag. (In Norwegian)

Christiansen, J.P. \& Kristiansen, J. 1975. Fuglelivet i Asker og Bærum. Asker og Bærum Feltornitologiske Forening. (In Norwegian)

Dale, S., Andersen, G.S., Eie, K., Bergan, M. \& Stensland, P. 2001. Guide til fuglelivet i Oslo og Akershus. Norsk Ornitologisk Forening, Oslo og Akershus. (In Norwegian)

Fjeldså, J. 1994. Toppdykker Podiceps cristatus. Pp. 36-37 in: Gjershaug, J.O., Thingstad, P.G., Eldøy, S. \& Byrkjeland, S. (eds.). Norsk fugleatlas. Norsk Ornitologisk Forening, Klæbu. (In Norwegian) 
Green, M., Haas, F. \& Lindström, Å. 2019. Övervakning av fåglarnas populationsutveckling. Årsrapport för 2018. Lunds Universitet. (In Swedish)

Haftorn, S. 1971. Norges Fugler. Universitetsforlaget, Oslo. (In Norwegian)

Huntley, B., Collingham, Y.C., Willis, S.G. \& Green, R.E. 2008. Potential impacts of climatic change on European breeding birds. PLoS ONE 3: e1439.

Keller, V. 1989. Variations in the response of great crested grebes Podiceps cristatus to human disturbance - a sign of adaptation? Biological Conservation 49: 31-45.

Keller, V. \& Korner-Nievergelt, P. 2019. Effect of trophic status of a deep-water lake on breeding Great Crested Grebes Podiceps cristatus during a phase of recovery from eutrophication: a long-term study. Bird Study 66: $1-10$.

Kålås, J.A., Dale, S., Gjershaug, J.O., Husby, M., Lislevand, T., Strann, K.-B. \& Strøm, H. 2015. Norsk rødliste for arter 2015. Fugler Aves. Artsdatabanken.

Monthouel, M. \& Dale, S. 2019. Population decline of the Eurasian Curlew in Akershus, southeastern Norway. Ornis Norvegica 42: 19-27.

Nordre Øyeren Fuglestasjon. 1984. Nordre Øyeren. Rapport 1977-1983. Toppdykker'n supplement nr. 3 1984. (In Norwegian)

Olsen, O. 1982. Hekkende våtmarksfugl i Oslo og Akershus. Toppdykker'n 5: 5-34. (In Norwegian)

Opheim, J. 2017. Kartlegging av hekkende rødlistearter i rike vannmiljøer Oppland fylke. Report, Norsk Ornitologisk Forening, avdeling Oppland. (In Norwegian)
Ottosson, U., Ottval, R., Elmberg, J., Green, M., Gustafsson, R., Haas, F., Holmqvist, N., Lindström, Å., Nilsson, L., Svensson, M., Svensson, S. \& Tjernberg, M. 2012. Fåglarna i Sverige - antal och förekomst. Sveriges Ornitologiska Förening, Halmstad. (In Swedish)

Rodenhouse, N.L., Sherry, T.W. \& Holmes, R.T. 1997. Site-dependent regulation of population size: a new synthesis. Ecology 78: 2025-2042.

Shimmings, P. \& Øien, I.J. 2015. Bestandsestimater for norske hekkefugler. Norsk Ornitologisk Forening, rapport 2-2015. (In Norwegian)

Siegel, S. \& Castellan, N.J. 1988. Nonparametric statistics for the behavioral sciences. McGraw-Hill. New York.

Svensson, S., Svensson, M. \& Tjernberg, M. 1999. Svensk Fågelatlas. Sveriges Ornitologiska Förening, Stockholm. (In Swedish)

Väisänen, R.A., Hario, M. \& Saurola, P. 2011. Population estimates of Finnish birds. In: Valkama, J., Vepsäläinen, V. \& Lehikoinen, A. 2011. The Third Finnish Breeding Bird Atlas. Finnish Museum of Natural History and Ministry of Environment (http://atlas3.lintuatlas.fi/ english).

Woollhead, J. 1987. A method for estimating the number of breeding pairs of Great Crested Grebes Podiceps cristatus on lakes. Bird Study 34: 82-86.

Økland, J. \& Økland, K.A. 1998. Vann og vassdrag 3. Kjemi, fysikk og miljø. Vett \& Viten, Nesbru. (In Norwegian)

Received 10.02.2020. Accepted 15.04.2020 
Appendix 1. Overview of sites in Oslo and Akershus counties, southeastern Norway, where Great Crested Grebes have been observed during the breeding season, but not accepted as breeding sites in the present study.

\begin{tabular}{|c|c|c|}
\hline Site & Municipality & Comment \\
\hline Bondivann & Asker & Pair recorded once, in 2018 \\
\hline Gjellumvann & Asker & $\begin{array}{l}\text { Irregular until } 2014, \text { present } 2015-18, \\
\text { may have attempted breeding }\end{array}$ \\
\hline Autenvann & Aurskog-Høland & $\begin{array}{l}\text { Bred } 1975 \text {, no pairs seen later and site } \\
\text { normally not suitable for breeding }\end{array}$ \\
\hline Bogstadvannet & Bærum, Oslo & A few records, early May only \\
\hline Vågvann & Enebakk & $\begin{array}{l}\text { Irregular records in breeding season, } \\
\text { family recorded october } 2016\end{array}$ \\
\hline Langen & Enebakk, Ski & Pair recorded once each in 2015 and 2016 \\
\hline Hurdalselvdeltaet & Hurdal & Pair recorded once in 2006, and early 2012 \\
\hline Langvannet & Lørenskog & Single bird 2011 \\
\hline Maridalsvannet & Oslo & A few records, mainly early May \\
\hline Nebbursvollen & Skedsmo & Irregular records in breeding season \\
\hline Ljøgodttjern & Ullensaker & Pair recorded once, in 2016 \\
\hline
\end{tabular}




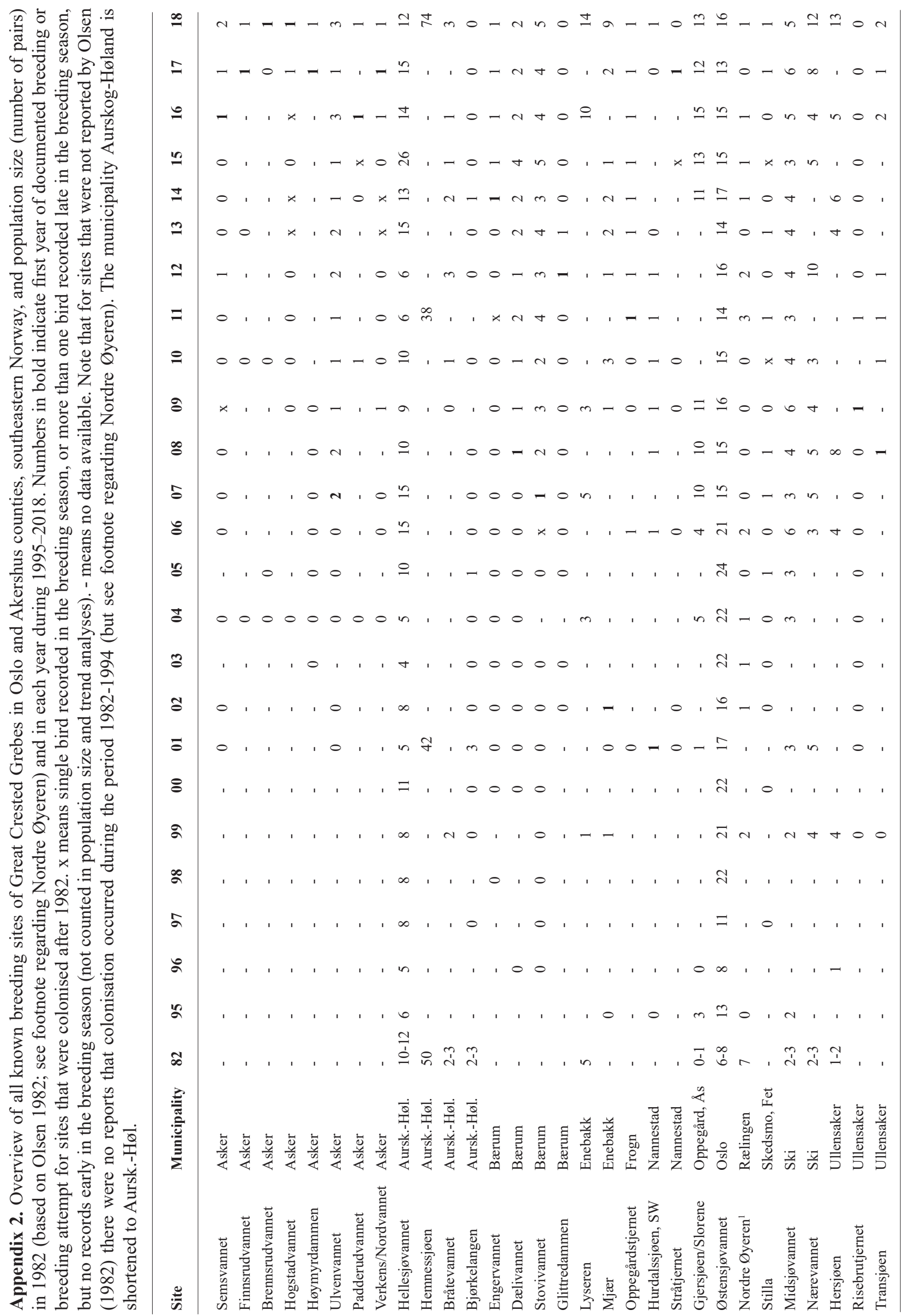




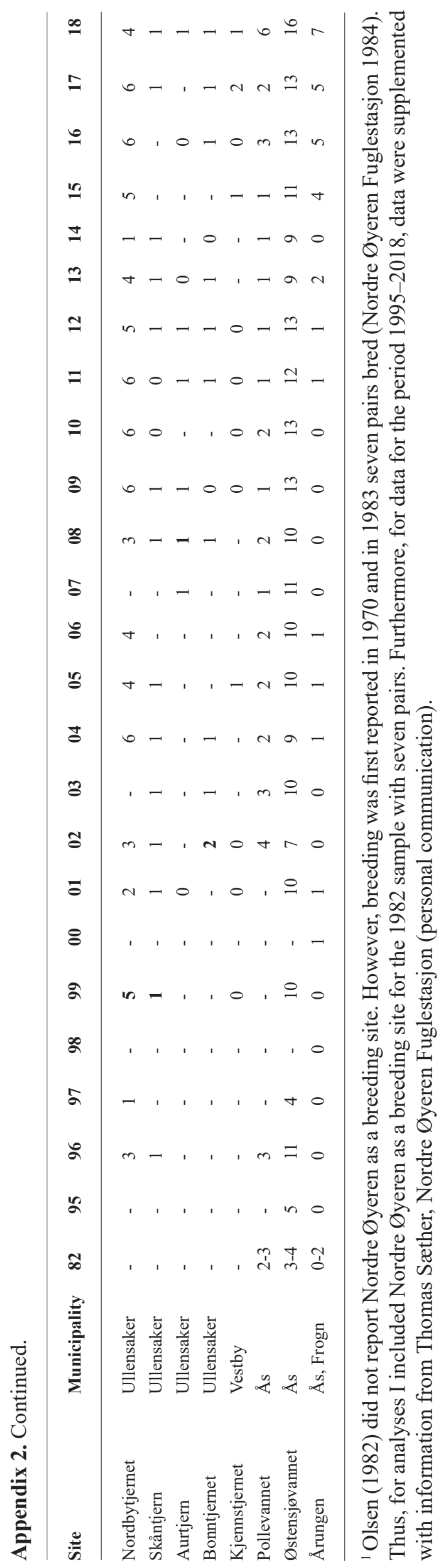

